Covered in: ERIH PLUS, CEEOL, Index Copernicus, CrossRef, CrossCheck, J-Gate, Google Scholar, Ideas RePeC, Econpapers, Socionet, KVK, WorldCat.

2020, Volume 9, Issue 1, pages: 139-154 | doi: 10.18662/lumenss/9.1/39

\section{The Principles of Bioethics and their Use in Ethical Decision-Making}

\section{Antonio SANDU ${ }^{1}$}

${ }_{1}^{1}$ Professor PhD Hab., Ştefan cel Mare University of Suceava, Romania, antonio1907@yahoo.com
Abstract: The term "bioethics" comes from the Greek terms bios - life and ethos - ethics, that is, the ethics of life. Thus, bioethics represents a particular branch of research within the wider sphere of applied ethics. Bioethics tries to answer the question: what are or what should be the desirable behaviors of humanity in general, and individuals in particular, when faced with the situations in which each is placed, due to the state of health and participation in health care, on the one hand, and on the development of technologies that bring along new threats to humanity, in addition to those that humanity seeks to diminish or eliminate, on the other.

Keywords: bioethics; pandemics; ethical decision; ethical principles; euthanasia; abortion.

How to cite: Sandu, A. (2020). The Principles of Bioethics and their Use in Ethical Decision-Making. Logos Universality Mentality Education Novelty: Social Sciences, 9(1), 139-154. doi: 10.18662/lumenss/9.1/39 


\section{Introduction}

Within bioethics, the desirable responses to threats to public health, and also issues such as organ transplantation, are addressed in a prescriptive manner. Bioethics discusses the time when organs can be harvested, in correlation with the idea of brain death, which appeared as another definition of death, precisely to make it possible for medical practitioners to perform such transplants. This definition also appears to be correlative with the idea of death as it was understood so far as the definitive cardiorespiratory arest. Cerebral death means the body is unable to recover the functions of the upper nervous system. It is practically irreversible, which allows the harvesting of organs.

In the specialized literature (Verheijde, Rady, \& Potts, 2018; Russell et al., 2019) there are a number of discussions regarding the acceptability of the idea of brain death as the limit of life. These include arguments both in favor of and against the risks of malpractice, and also approaches about possible criminal intentions when labeling a state of deep coma as brain death in order to allow faster organ harvesting.

Starting from here, we can discuss about the principles of bioethics, which were first formulated by Beauchamp and Childress (1979). The principle of charity or beneficence states that the purpose of any action in the medical system is to do good, and is correlated with the principle of not doing harm, of non-maleficence. This second principle originates from the Hippocratic oath, which first requires the physician to refrain from doing harm through his medical practice. This principle of non-maleficence means the abstention from any willful harming act.

Within the same principle of non-maleficence, the scientific literature (Mihailov, 2017) sometimes includes therapeutic treatment (Alvas, 2013). This is the situation when therapy is continued for certain incurable diseases, beyond the limits where there are chances of healing or improvement, or which puts the patient in unnecessary stressful situations or even in degrading and humiliating situations. There must be a balance between beneficence and non-maleficence.

An example of unpleasant situation that may occur in the current period, during the crisis caused by the Coronavirus pandemic, related to people who do not show any symptoms of the disease and who do not test positive, but are, however, placed in isolation at home or even quarantined if they come from areas at high risk of Coronavirus infection. This approach to quarantine, as a specific response to threats to public health, can be interpreted from the point of view of individuals in quarantine, but also of 
those in self-isolation and who have not had contact with people infected with the virus in question, as personal harm, but necessary for public health, thus responding to the requirement of public good.

A third principle discussed is that of respect for the autonomy of the individual, the patient, the person. This principle stems from the ideas expressed by Immanuel Kant (2010), namely, that the human person is and should always be treated as a purpose and not as a means.

The principle of respect for the autonomy of the person, derived from Kant's work $(2007$; 2010), is transposed into current medical ethics through the necessity of informed consent, although it involves much more than that. The idea of informed consent represents the right of the patients to know what their health condition is, and to decide knowingly on the treatments they are subjected to, and any experiments or any other form of research on human subjects in which they participate. It incorporates the guaranteed right to decide at any time to withdraw from treatment or medical research or any other form of investigation that concerns one's own health or well-being.

The current pandemic conditions, imposed from the perspective of public health, limit the observance of this principle, focusing on the need for the health security of citizens and public good, in order to limit the risk of infection. This perspective of prioritizing public good leads to health policy decisions that impose large-scale quarantine and border closures, thus limiting the right of free movement even within the European Union. Thus, the limits of the right to self-determination, autonomy and public good represent an ethical dilemma that the whole world is confronted with today at an unprecedented level for the postmodern society.

Starting from the analysis of the ethical dilemmas involved in possible conflicts between principles, the problem of euthanasia can be discussed. This relates to the expression of the person's autonomy in the context of ending one's life on request versus the abstention from doing harm, that is required of doctors by both the second principle of bioethics as well as the Hippocratic oath. In addition to the right to autonomy, one can also discuss the right to dignity.

Another topic is that of abortion, as an important bioethical issue that generates a dilemma of choosing between the right to life of the unborn child versus the right of the woman to decide about her own body. The decision on abortion prevails over the right of the woman to decide about her own body, her own organism - that is, her autonomy - at the expense of the right of a still unborn person, that is to say, of a being to whom the right to be a person and, implicitly, the right to dignity is not recognized. 
In the scientific literature, there has been a discussion about the acceptability of infanticide being renamed as "postnatal abortion". It concerned the right of the family to request euthanasia of children born with particularly serious malformations and whose life prognosis is limited. The author of the controversial hypothesis is Alberto Giubilini (2013), who pointed out that if abortion is acceptable based on the fact that, in the absence of self-awareness, aborted fetuses do not have a legitimate interest in life, since they do not have the consciousness of losing it, the same arguments should be in favor of euthanizing newborns. The main argument was that the awareness of newborn children regarding their own interest in living is not much different from that of aborted fetuses. In neither case is self-awareness present and, apparently, neither is the awareness of imminent death. As such, the mere fact of being born should not confer additional rights to newborns, as long as the right to life is presumed to derive from a self-awareness that they do not yet have. It can be considered that, from the perspective of the right to life, this could create a situation of inequity between newborn children (even if they are born with severe malformations, including cerebral palsy or other severe infirmities, with a limited life prognosis and with the prospect of suffering chronic pain) compared to aborted fetuses (who could be viable persons and could be born with a perfect health condition). By accepting abortion, but rejecting euthanasia of newborn babies, society discriminates based on the criterion of "the time of birth". The above-mentioned article discusses the acceptability of euthanasia and abortion alike.

Starting from the idea of inequity in protecting the right to life, one can open the discussion of inequity in general, and from here on the fourth principle of bioethics, that of social equity or justice, is brought into question. In health care, issues related to respect for social justice and fairness often arise, because society does not have the capacity to ensure access to health equally for everybody and according to the needs of each person.

In Italy, during the outbreak of Coronavirus infection, there was an extremely severe triage of people requiring artificial ventilation. This process considered which people would receive and not receive artificial respiration, who were practically worthy and who were not guaranteed the right to health and life, and which were the criteria to ethically restrict the right to life of a person, knowing that by not being admitted to intensive care, there was a major risk of death (DG, 2020).

The decision taken by the Italian health authorities for hospitals in the most affected area was to admit young people to intensive care, because 
they had a life expectancy and healing chances greater than that of the elderly. Thus, discrimination on the basis of age appears in the provision of health services and life-saving services, which we understand to be an inequity in health care.

It is very clear that the right to health cannot be fulfilled under optimal conditions for all patients and under any conditions. The possibility of innovative treatment and access to particularly expensive therapies can be discussed here. These are often limited depending on the person's ability to contribute additionally to the health insurance that he has voluntarily paid or that was withheld, ex officio, from the incomes that he/she has produced, according to the law governing public health systems and health insurance in one country or another.

\section{The four principles of bioethics - Various applications in concrete situations}

\subsection{Abortion}

Abortion is a problem that has aroused, and still arouses, endless discussions, because it is unacceptable from a religious ethics' point of view. It is also unacceptable to many people from a bioethical standpoint - in humanistic bioethics. Many authors (Fromer, 1982; Hewson, 2001; Gillon, 2001; Jones, \& Chaloner, 2007), although not Christian-centered, are ultimately inspired by Christian ethical values, values that they transfer to the bioethical discourse (Aburel et al., 1962; Stan, 2001; Boyle, 2004).

The abortion issue is a public policy issue. In Romania, abortion was forbidden during the communist totalitarian regime, in an extreme way, which resulted in a high number of victims among women who underwent illegal abortions. In communist Romania, there was a total restriction of abortion, even when the mother's serious health problems would have recommended it. This public policy approach can itself be catalogued under the risk of violating the principle of non-maleficence, as long as an absurd refusal by the state, and sometimes doctors, to accept abortion in strictly determined medical situations leads to the death of both the mother and the child, practically to the destruction of two lives, when at least one of them could have been saved. Except for these particular situations, the discussion places the issue in the sphere of a choice between the subjective right of the mother to self-determination and that of the unborn child.

People who consider abortion to be acceptable say that giving birth to a child but abandoning him, even in the maternity hospital, is in fact a condemnation of that child to suffering, to the limitation of his right to life, 
the right to happiness and so on. Opponents of this point of view believe that regardless of the conditions in which an individual's life unfolds, the right to life prevails before the mother's particular interests and that being born and living is better than not living at all.

\subsection{Euthanasia}

The problem of euthanasia must be approached from many angles, because it is very complex. We can consider that the right to finitude of life is one that should be correlative with the right to life. When pain is extremely strong, such that it does not give in to strong painkillers such as morphine, but not only in this situation, a person should decide when and under what conditions he or she can give up one's own life. We can question the fact that there are limits to this right. There was a case of euthanasia that was approved a few years ago. It related to a person with severe depression (Pressly, 2018), a young woman who decided that life was not worth living for her and that it was a burden because of her mental health, depression, and not due to an organic condition, an unbearable pain of a physical nature. Eventually she was allowed euthanasia, by a court decision and on the basis of opinions, including from ethics committees, on the grounds of mental health and not of incurable somatic disease.

Accepting euthanasia of people suffering from mental illnesses, as is the case of the person presented above, opens up a series of delicate problems. The person may no longer see the meaning of life, easily appealing to euthanasia due to severe depression caused by the losses in one's life. Even without considering the option of euthanasia, many people resort to suicide when they suffer from depression. Euthanasia would mean that society would grant them the right to assisted suicide and ease their terminal gesture.

From a religious point of view, euthanasia is unacceptable because life itself is sacred. For the same reason, abortion is not accepted either. The sacredness of life is practically the argument that rejects any form of counterargument related to the right to euthanasia. Whilst the Christian religion states that the savior Jesus Christ suffered a terrible agony for the salvation of humans, resorting to euthanasia to lessen their suffering cannot be a valid argument for Christians. They focus on following the example of Jesus Christ in the form of imitatio Christi, that His suffering should be an example in accepting one's own suffering. On the other hand, there are people who cannot assume, and cannot accept without limitation, their suffering. In this case, the end of this suffering, even if it is not acceptable 
from a Christian and generally religious point of view, could be a fully accepted right from a civil rights point of view.

The so-called passive euthanasia is the disconnection from devices in situations where it is inappropriate to continue life, sometimes also known as refusing to practice therapeutic hardening. For example, Israel is a state where device decoupling is prohibited. In this situation, it is possible to analyze the case of a hospital where the intensive care clinic is completely occupied by people in vegetative states with a prognosis of zero resuscitation, but who cannot be disconnected from devices. If, in that hospital, it is necessary to hospitalize new patients who have a chance of recovery, but there are no free beds, the hospital must refuse their admission. We are discussing a more or less hypothetical situation, but unfortunately the situation was similar recently in Italy, when the triage of patients suffering from Coronavirus infection imposed a decision about the artificial ventilation of a patient.

The problems we consider as life and death situations are actually current problems that healthcare professionals face, and to which bioethics must provide an immediate response. This makes medical ethics a little different from the ethics of everyday life. It is what we sometimes call the ethics of extreme situations. It is the ethics of situations where both options can have negative consequences. In bioethics, we try to formulate such problems in such a way as to provide decision-making tools. Bioethical principiism - the four principles I spoke of, formulated by Beauchamp and Childress (1979) - aims to be such an instrument of ethical decision-making. This is a way taht the individual, the physician or the therapist can use in order to decide on an intervention, on an experiment, or a practice in general.

\subsection{Mandatory vaccination}

Julian Savulescu raises a series of problems related to the possibility that humanity may not be adapted to future conditions, especially following the development of medical technology (Savulescu, 2001; Savulescu, \& Kahane, 2009; Persson, \& Savulescu, 2012). He introduces the idea of moral bio-enhancement, emphasizing problems that current ethics also raise, namely precisely these dilemmas of conflicting principles and how they will be solved in a future society.

We believe that, if the current crisis in public health, caused by the wide spread of the Coronavirus, does not completely change the path of future society, we will live in a society where technology is advancing, where life expectancy is increasing, while also facing the risks of the emergence of 
new pathogens, even though many of the traditional pathogens have been eliminated. At this point, another problem raised by current society, and which has yet to receive an answer from a bioethical perspective, is the ethical and social acceptability or unacceptability of mandatory vaccination.

\section{Emerging medical technologies - Towards anthropological change}

Mandatory vaccination reduces polio and other diseases that have decimated entire populations for decades. Antibiotics have decreased mortality due to bacterial infections; antiviral vaccines have appeared; even total cure treatments for HIV/AIDS have emerged. Today, medicine makes amazing progress. Intensive therapy and artificial ventilation have been developed which enable many lives to be saved and prolonged. Various forms of transplantation have occurred. A number of other technologies are emerging that will lead to what we have called new anthropological uniqueness. The term anthropological singularity is somewhat correlative with the idea of technological singularity. Technological uniqueness has been defined as the situation where Artificial Intelligence becomes more complex or at least reaches the same level of complexity as human intelligence. Currently, supercomputers exceed human intelligence. This poses a number of ethical risks. Technoethics is a branch of applied ethics, complementary to bioethics, because it discusses the changes experienced in the course of the human life due to technologies, including medical.

There are a number of risks that technological development, such as Artificial Intelligence, but also biomedical technologies, can bring. These include the increase of social inequities, because such therapies that extend life indefinitely are not accessible to all, but only to those who benefit from a certain material prosperity. There is a whole literature on the fact that research is undertaken on the indefinite extension of life. In such cases, we will approach immortality, either through continuous transplants from one body to another, or through the transfer of consciousness into robotic bodies or even the digitization of consciousness (Choe, Kwon, \& Ryangchung, 2012; Canavero, 2013; Tayag, 2015; Čartolovni, \& Spagnolo, 2015; Farhud, 2018; Stuart, 2018; Parry, 2019; Robson, 2019). As long as it is not yet clear whether we will be able to transfer consciousness from one body to another physical/biophysical or digital one, we are not yet sure that such a transplant will be possible in the near future. However, there are already inventions that allow neurons to communicate with artificial neurons (Gent, 2019; Serb et al., 2020). In practice, such a transfer of mental content, of consciousness, to another body - be it biological or computer-made - can 
be thought of in the sense of not necessarily obtaining immortality, but still a very large extension of life expectancy.

Other technologies besides those aimed at increasing lifespan are those aimed at moral bio-enhancement (Persson, \& Savulescu, 2012; Lo Sapio, 2014). Humanity, due to current scientific and technological developments, has the possibility of creating, through pharmacological or genetic methods, seemingly better, morally bettered individuals. By inhibiting the aggressiveness of a person, he/she will be more docile, less prone to conflicts, and society will face fewer immoral decisions, fewer criminal acts. Person who are genetically programmed to have an increased level of fear through hormonal imbalances or by altering the activity of some neurotransmitters - can reach a state where they are extremely docile, not because their own moral conscience/autonomy dictates it, but because they were biologically modified.

Julian Savulescu (2002) sets an example in one of his works - a community in which all people are deaf and where a person who is deaf will be excluded or at least marginalized. The idea of marginalizing different people is not a new one. Ioan Petru Culianu (2015) explains the development of modern Western society, beginning with Renaissance, when people who had scientific interests, although pursued by the Inquisition, transformed society through science. This evolved into what we now call a knowledge-based society.

\section{Bioethics and moral values in society - The road to transcendence}

Every society, every nation, has a number of moral values. I conducted a comprehensive study on the values of ethics in today's Romanian society, a study I published in the Journal for the Study of Religion and Ideologies (Sandu, Huidu, \& Frunză, 2020). Also, a larger presentation of this study is available at the Library of the Center for Applied Ethics of Stefan cel Mare University in Suceava, where the study was developed. We analyzed the issue of national values in the current context from the perspective of the impact these values have and their acknowledgement in society. The results obtained show that the values of the citizens from North-Eastern Romanian are of religious origin, more specifically Orthodox Christian.

Euthanasia, like other problems constantly in the attention of bioethicists, is approached from a Christian perspective means to accept your condition of health, among others, because it is allowed by God, even if it is not His will that you suffer. Suffering is seen as a challenge that the individual must face, hat is useful for spiritual growth. The idea of accepting 
suffering as an everyday element of life is not a new idea. It is also common in other cultural spaces - from the Catholic to the Far East. The contemporary, postmodern society is one that shies away from pain, but also from assuming liability and responsibility. We are talking about a minimalistic ethics, an ethics in the "twilight of duty" (Lipovetsky, 1996), an ethics of people who are rather selfish and individualistic. We observe such a selfish ethics in the current situation of the pandemic, when people who are not necessarily infected but are suspected of being infected, especially those who come from high risk areas and who are placed in self-isolation at home, remove themselves from isolation and go outside their homes without being responsible or concerned about the possibility of infecting others.

The post-industrial society, the postmodern society, places great emphasis on individualism, on the individual, on his ego, and especially on the fact that he must feel good. It is a consumerist society and the values of consumerism are the values of attractive goods, and of an immediate sense of good. All these are called surrogates (Baudrillard, 1994) - but they are surrogates of love, equity, justice and so on. This makes us imagine a society as prosperous as possible, as prosperity and not development, spiritual or of another nature, is the central value of today's society. And then, this prosperity, this rush for wealth, leads to the idea of bypassing not only evil, but also the idea that evil can exist.

Artificial transcendence is thought of in our century - and we discuss here another work, that of Noah Harari, Homo Deus (2017) - starting from the idea that humanity has reached another ontological condition. That, at least compared to our ancestors, positions us in the situation of not being human anymore but of being another species, one of gods, for example. If this pandemic had occurred in the nineteenth or seventeenth century, it would probably have produced about the same number of casualties as the plague. However, the measures taken by humanity, including mechanical ventilation, intensive care and so on, reduce the risk of death. We are not yet in a position to be immortal, like the gods, but we have a longer lifespan.

A particle accelerator in China has re-created the temperature conditions of the sun. Sputnik was the first satellite of its kind, as the first artificial moon on Earth. Hence, we have the sun, not as great as the real one, but still existing on Earth, in the form of particle accelerators such as the Large Hadron Collider in Switzerland. We have artificial moons satellites that are used today in telecommunications and GPS technology, including military applications; we have artificial stars. Basically, we are virtualizing the space (Sandu, 2003; Sandu, Cojocaru, \& Ponea, 2010; Sandu 
2019a; 2019b; 2011). We are in a situation where the interactions between us are now virtual, the distances are no longer a problem, we are in a virtual ubiquity - here is another characteristic of the transcendence: the ubiquity to be at the same time anywhere.

In a society in which there is diversity and the principles of life differ from man to man, the value system being influenced by the level of education and social status, can we talk about fair decision-making tools in bioethics?

We will not have fair decisions for each individual. We will have acceptable decisions. Bioethics, at least the principled one that is brought to us by Beauchamp and Childress (1979), can be understood as a decision system based on social acceptability. Ethics in general has been - at least as Aristotle (2003) has shown us - a guide to good conduct. It is about Stagirit's teachings to his son Nicomah. Traditionally, it is considered that an ethicist, a specialist, can tell everyone what is good and what is bad in society, and society should follow these ideas. Religious ethics impose a number of principles. The Decalogue, the Code of Hammurabi, the Manavadharmashastra - in various spiritual traditions - are such mandatory ethical codes to be respected by followers of the respective religion or spirituality.

In general, today's ethics tends to encode behaviors. When we talk about social and ethical acceptability, we refer to the way in which the dominant values are perceived in society. Acceptability is based on the consensus of the majority; it is the principle of democracy in ethics. An acceptable decision is considered by most members of the respective community. In opposition to acceptability we have desirability, which meets the highest standards considered to be desirable by most members of the respective interpretive community.

In opposition to the deliberative ethics discussed above, which is based on social consensus (Habermas, 2000), modern ethics is an imperative ethics. Kant (2013) speaks of the "categorical imperative". Imperative ethics says that something must, regardless of the will of the majority, simply because it is right, because ethical experts (Reamer, 2007; FrUN, 2012) know how it is best to proceed. In bioethics, we also have trends that favor the idea of ethical expertise (Caras, \& Sandu, 2013; Frunză, \& Sandu, 2018; Frunză, 2012). The ethics of principiism, the most widely used in bioethics, is based on the idea of a "democratic ethics", of ethics based on the acceptance of the majority. Therefore, the problems of abortion, euthanasia and so on, are treated in the sense that they are accepted by a large or small majority. Of course, these principles are modulated with respect for human 
rights and respect for the dignity of the person. But, in principle, bioethical acceptability is related to social acceptability and has a quasi-democratic character.

\section{Conclusions}

When we conducted the study on ethical values, published in the Journal for the Study of Religion and Ideologies (Sandu, Huidu, \& Frunză, 2020), we showed that the ethical reflection that most individuals have is liminal that is, particularly low. In general, we do not face ethical problems unless they arise in the form of dilemmas that demand immediate solutions and then it is quite late to make long-term decisions, for which there is a social consensus. Communicative action (Habermas, 2000) is the kind of social action aimed at obtaining public consensus. Not all public policies can be based on consensus and decision-making transparency. In our case, we believe that a short-term public consensus on health policy decisions, such as those aimed at limiting public activities and closing schools, cannot be reached. There is no consensus on this decision because at present there are many parents who have great problems overseeing their children who are at home due to the disruption of school and kindergartens. Parents have no one to leave at home to supervise them when they have to be at work. This requires special measures, work from home, special leave for child care, and so on ${ }^{1}$. However, in this situation, the imperative character of these measures is apparent. Otherwise, ethical decisions should also have a democratic basis. I personally am a follower of a (bio) ethics that combines the idea of ethical expertise, of an imperative-normative type, with the democratic ethics of decisions based on communicative action.

\section{References}

Aburel, E., Căprioară, D., Coja, N., Dobrovici, V., Gheorghiu, N.N., Lorincz, A.E., Protopopescu-Pache, I., Popescu, D. D. (1962). Obstretică şi ginecologie. In E. Aburel, D. Caprioara, N. Coja, V. Dobrovici, N.N. Gheorghiu, A.E. Lorincz, I. Protopopescu-Pache, D.D. Popescu, (Coords.), Obstretică şi ginecologie. Manual pentru invatamintul medical superior (pp. 84-85). București: Editura Medicală.

\footnotetext{
1 These measures were adopted in the form of public policies during the state of emergency, together with increased social isolation required as much as possible from the entire population.
} 
Alvas, M. (2013). Moarte. Eutanasie. Suicid asistat. Retrieved from https://www.scribd.com/doc/253540212/Bioetica-Eutanasia-Seria$\underline{\text { I\#logout }}$

Aristotle (2003). Etica Nicomabică. Bucureşti, România: Editura Antet Revolution

Baudrillard, J. (1994). Simulacra and Simulation, trans. S. F. Glaser. Ann Arbor: University of Michigan Press.

Beauchamp, T. L., \& Childress, J. F. (1979). Principles of biomedical ethics. New York : Oxford University Press

Boyle, J. (2004). Abortion and Christian Bioethics: The Continuing Ethical Importance of Abortion. Christian Bioethics, 10(1), 1-5.

Canavero, S. (2013). Heaven: The Head Anastomosis Venture Project Outline for the First Human Head Transplantation with Spinal Linkage (GEMINI). Surg Neurol Int, 4 (Suppl S1), 335-342.

Caras, A., \& Sandu, A. (2013). Ethical Evaluation of Social Services and the Need for Ethics Committees. Procedia - Social and Behavioral Sciences, 92, 142-149. ISSN: 1877-0428. DOI: 10.1016/j.sbspro.2013.08.650

Čartolovni, A., \& Spagnolo, A. G. (2015). Ethical considerations regarding head transplantation. Surgical Neurology International, 6, 103. https://doi.org/10.4103/2152-7806.158785

Choe, Y., kwon, J., \& Ryangchung, Ji. (2012). TIME, CONSCIOUSNESS, AND MIND UPLOADING. International Journal of Machine Consciousness, 4(1). 257-274. Doi: 10.1142/S179384301240015X.

Culianu, I. P. (2015). Eros şi magie în Renaştere. Iaşi, România: Editura Polirom

D.G. (2020 Martie 10). Coronavirus. Medicii italieni din prima linie, confruntați cu decizia dificilă de a alege pe cine salvează. Hotnews.ro. https://www.hotnews.ro/stiri-esential-23712630-Coronavirus-mediciiitalieni-din-prima-line-confruntati-decizia-dificila-alege-cine-salveaza.htm

Farhud, D. D. (2018). Ethical, Social \& Psychological Challenges of Head Transplantation in Human. Iranian Journal Of Public Health, 47(9), 12321234.

Fromer, M. J. (1982). Abortion ethics. Nursing Outlook, 30(4), 234-40.

Frunză, A. \& Sandu, A. (2018). Supervision of Ethics in Social Work Practice. A Reconstruction of Ethics Expertise. In A. Sandu, \& A. Frunza, (Eds.), Ethical Issues in Social Work Practice (pp. 175-204). SUA: IGI Global.

Frunză, M. (2012). Expertiza etică şi acţiune socială. Bucureşti, România: Editura Tritonic.

Gent, E. (2019, December 6). First-Ever Artificial Neuron Could Let Us Repair Brain Injuries with Silicon. SingularityHub. https://singularityhub.com/2019/12/06/ first-ever-artificial-neuron-couldlet-us-repair-brain-injuries-with-silicon/ 
Gillon, R. (2001). Is there a 'new ethics of abortion'? Journal of Medical Ethics, 27

Suppl 2, ii5-9. https://doi.org/10.1136/jme.27.suppl 2.ii5

Giubilini, A. (2013). Minerva FAfter-birth abortion: why should the baby live? Journal of Medical Ethics, 39, 261-263.

Habermas, J (2000). Conştiințta morală şi acțiunea comunicativă. Bucureşti, România: Editura All Educațional.

Harari, Y. N. (2017). Homo Deus. A Brief History of Tomorrow. Vintage Publishing. Hewson, B. (2001). Reproductive autonomy and the ethics of abortion. Journal of Medical Ethics, 27, ii10-ii14.

Jones, K., \& Chaloner, C. (2007). Ethics of abortion: the arguments for and against. Nursing Standard, 21(37), 45-48. DOI: 10.7748/ns2007.05.21.37.45.c4559

Kant, I. (2007). Intemeierea metafizicii moravurilor. Bucureşti: Editura Humanitas.

Kant, I. (2010). Critica rațiunii practice. Bucureşti: Editura Univers Enciclopedic.

Kant, I. (2013). Metafiz̧ica moravurilor. Bucureşti, România: Editura Antet Revolution

Lipovetsky, G. (1996). Amurgul datoriei. Etica nedureroasă a noilor timpuri democratice. Bucureşti, România: Editura Babel

Lo Sapio, L. (2014). Biomoral Enhancement. Definizioni e problemi aperti. Scienza \& Filosofia, 12, 102-120. http://www.scienzaefilosofia.com/wpcontent/uploads/2018/03/res686079 09-LOSAPIO.pdf

Mihailov, E. (2017). Complexitatea judecării morale: limitele abordărilor procedurale şi tipuri de contexte / The complexity of moral decision making: limits of procedural approaches and types of contexts. Ideo: Romanian Journal of Philosophical and Social Studies, 2(1), 51-66. Published online on May 17, 2018 at: http://ideo.acadiasi.ro/sites/default/files/papers/Ideo-2017-1-04.pdf

Parry, L. (2019, March 29). HEAD CASE Scientists planning the world's first head transplant say they're ready to start human trials. Sergio Canavaro and Xiaoping Ren say they've repaired 'irreversible' spinal cord injuries in dogs and monkeys. The Sun. https://www.thesun.co.uk/ news /8745721/scientists-worlds-first-head-transplant-ready-human-trials /

Persson, I., \& Săvulescu, J. (2012). Unfit for the future: The need for moral enhancement. Oxford, Regatul Unit al Marii Britanii: Oxford University Press.

Pressly, L. (2018, August 9). The troubled 29-year-old helped to die by Dutch doctors. BBC News, The Netherlands. https://www.bbc.com/news/stories$\underline{45117163}$

Reamer, F. G. (2007). Conducting an Ethics Audit. Social Work Today 7(1). Retrieved from https://www.socialworktoday.com/archive/EoEJanFeb07.shtml 
Robson, D. (2019, March 27). Giulio Tononi’s "integrated information theory" might solve neuroscience's biggest puzzle. BBC.com.

https://www.bbc.com/future/ article/20190326-are-we-close-to-solving-the-puzzle-of-consciousness

Russell, J.A., Epstein, L.G., Greer, D.M., Kirschen, M., Rubin, M.A., \& Lewis, A. (2019). Brain death, the determination of brain death, and member guidance for brain death accommodation requests. Neurology, 92(5), 228232. DOI: 10.1212/WNL.0000000000006750

Sandu, A. (2003). Sexul pe internet - formă de virtualizare a spaţiului social. Revista de Cercetare și Intervenție Socială, 2, 154-161.

Sandu, A. (2011). Quantum Metaphysics. Postmodern Openings, 2(6), 7-22.

Sandu, A. (2019a). Towards a Phenomenology of the Digitalization of Consciousness. The Virtualization of the Social Space. Postmodern Openings, 10(2), 155-161. doi: http://dx.doi.org/10.18662/po/77

Sandu, A. (2019b). New Patterns of Media Consumption. TV Series on Demand as a Form of Virtualizing the Social Space. Logos Universality Mentality Education Novelty: Philosophy \& Humanistic Sciences, 7(1), 96-105. doi: http:/ / dx.doi.org/10.18662/lumenphs/21

Sandu, A., Cojocaru, S.., \& Ponea, S. (2010). Appreciative evaluation of training programs. Case study: Lumen Consulting and Training Center, [Evaluarea apreciativă a programelor de training. Studiu de caz: Centrul de Consultanță şi Training Lumen]. Social Research Reports, 8, 3-76.

Sandu, A., Huidu, A., \& Frunză, A. (2020). Social Perception of Ethical Values in the Romanian Post-Secular Society. Journal for the Study of Religions and Ideologies, 19(55), 18-32.

Săvulescu, J. (2001). Procreative beneficence: Why we should select the best children. Bioethics, 15(5-6), 413-426. doi: https://doi.org/10.1111/1467$\underline{8519.00251}$.

Săvulescu, J. (2002). Education and debate: Deaf lesbians, "designer disability," and the future of medicine. BMJ (Clinical research ed.), 325(7367), 771-773. https://doi.org/10.1136/bmj.325.7367.771

Săvulescu, J., \& Kahane, G. (2009). The moral obligation to create children with the best chance of the best life. Bioethics, 23(5), 274-290. https://doi.org/10.1111/j.1467-8519.2008.00687.x

Serb, A., Corna, A., George, R., Khiat, A., Rocchi, F., Reato, M., Maschietto, M., Mayr, C., Indiveri, G., Vassanelli, S., \& Prodromakis, T. (2020). Memristive synapses connect brain and silicon spiking neurons. Scientific Reports, 10 , Article number: 2590 (2020). https://doi.org/10.1038/s41598-020-58831$\underline{9}$ 
Stan, G. (2001). Teologie şi bioetica - avortul. În G. Stan (Ed.), Teologie şi bioetica. Alexandria: Editura Biserica Ortodoxa.

Stuart, N. (2018, January 4). Future prosthetic: towards the bionic human. The Engineer. https://www.theengineer.co.uk/future-prosthetic/

Tayag, Y. (2015, July 29). Robotic Body Parts: A History Of Self Improvement. Inverse. https://www.inverse.com/ article/4920-robotic-body-parts-a-history-of-self-improvement .

Verheijde, J. L., Rady, M. Y., \& Potts, M. (2018). Neuroscience and Brain Death Controversies: The Elephant in the Room. Journal of religion and bealth, 57(5), 1745-1763. https://doi.org/10.1007/s10943-018-0654-7 